\title{
Late subclinical hemolysis and long-term outcomes after aortic valve replacement with On-X mechanical prostheses - a preliminary single-center report
}

\author{
Bartłomiej Perek ${ }^{1}$, Sylwia Sławek², Agnieszka Malińska3 ${ }^{3}$ Izabela Katyńska1 ${ }^{1}$, Mateusz Puślecki ${ }^{1}$, \\ Bogumiła Szymak-Pawełczyk ${ }^{4}$, Michał Nowicki ${ }^{3}$, Marek Jemielity ${ }^{1}$
}

${ }^{1}$ Department of Cardiac Surgery and Transplantology, Poznan University of Medical Sciences, Poznan, Poland

${ }^{2} 1^{\text {st }}$ Department of Cardiology, Poznan University of Medical Sciences, Poznan, Poland

${ }^{3}$ Department of Histology and Embryology, Poznan University of Medical Sciences, Poznan, Poland

${ }^{4}$ Department of Cardiology, Regional Hospital, Leszno, Poland

Kardiochirurgia i Torakochurirgia Polska 2017; 14 (3): 175-179

\begin{abstract}
Introduction: Aortic valve replacement (AVR) with a mechanical prosthesis is not free from late complications.

Aim: To evaluate the prevalence of subclinical hemolysis after AVR with On-X prostheses and assess its impact on long-term outcomes.

Material and methods: The prospective study included 84 consecutive patients aged $58.3 \pm 10.3$ years who underwent AVR. They were retrospectively split into group $\mathrm{H}(n=12 ; 14.3 \%)$ with prosthesis-related subclinical hemolysis and a control group (C; $n=72 ; 85.7 \%$ ). All operations were performed via median sternotomy using cardio-pulmonary bypass. At the end of follow-up, echocardiography was carried out and blood samples for morphology and biochemistry (lactate dehydrogenase (LDH), bilirubin, haptoglobin) were taken.

Results: The rate of subclinical hemolysis in patients with properly working prostheses was $14.3 \%$ and it was the highest (33.3\%) for the smallest valves. Although an improvement in functional status was noted in both groups, it was less evident in group $\mathrm{H}$ than in group $\mathrm{C}(p=0.007)$. At the end of follow-up, $97.2 \%$ in group $\mathrm{C}$ and $75.0 \%$ in group $\mathrm{H}$ were found in NYHA classes I and II. Patients in group $\mathrm{H}$ had significantly lower hemoglobin, hematocrit, and haptoglobin and higher LDH activity than group $\mathrm{C}$ subjects. In group $\mathrm{H}$, systolic gradients of On- $\mathrm{X}$ valves were higher whereas effective orifice area was smaller than in group $C$.

Conclusions: Our study proved that prosthesis-induced subclinical hemolysis is seen even after implantation of the latest generation mechanical prostheses, particularly of small diameter, and its degree may impact late outcome.
\end{abstract}

Key words: aortic stenosis, aortic valve replacement, mechanical prosthesis, hemolysis, late outcome.

\section{Streszczenie}

Wstęp: Wymiana zastawki aortalnej (AVR) na protezę mechaniczną nie jest pozbawiona późnych powikłań.

Cel: Ocena częstości występowania późnej hemolizy po zabiegach AVR z zastosowaniem protez On-X i jej wpływu na odległe wyniki kliniczne.

Materiat i metody: Prospektywnym badaniem objęto 84 kolejnych chorych w wieku 58,3 $\pm 10,3$ roku, których poddano zabiegom AVR. Podzielono ich retrospektywnie na grupę $\mathrm{H}$ ( $n=12 ; 14,3 \%)$ z subkliniczną hemolizą zależną od protezy oraz na grupę kontrolną (C; $n=72 ; 85,7 \%$ ). Wszystkie operacje wykonano ze sternotomii pośrodkowej z użyciem krążenia pozaustrojowego. Na zakończenie okresu obserwacji wykonywano badania echokardiograficzne oraz pobierano krew do badań morfologicznych i biochemicznych (dehydrogenaza mleczanowa (LDH), bilirubina oraz haptoglobina).

Wyniki: Zjawisko subklinicznej hemolizy obserwowano u 14,3\% osób z prawidłowo funkcjonującymi protezami mechanicznymi, przy czym najczęściej u ludzi z zastawkami o najmniejszej średnicy (33,3\%). Poprawę wydolności układu krążenia obserwowano w obu grupach, jednak w grupie $\mathrm{H}$ była ona mniej wyraźna niż w grupie $C(p=0,007)$. Na zakończenie okresu obserwacji odległej 97,2\% pacjentów w grupie C i 75,0\% w grupie $\mathrm{H}$ znajdowało się w klasach NYHA I i II. Chorzy w grupie $\mathrm{H}$ mieli istotnie mniejsze stężenie hemoglobiny, haptoglobiny i niższy hematokryt niż osoby z grupy kontrolnej. W grupie $\mathrm{H}$ gradient skurczowy przez protezy On-X był wyższy, a efektywna powierzchnia ujścia istotnie mniejsza niż w grupie $C$.

Wnioski: Badanie dowiodło, że nawet w najnowszej generacji protez mechanicznych, szczególnie o małej średnicy, stwierdza się zależną od zastawek subkliniczną hemolizę, a jej nasilenie może mieć wpływ na odległe wyniki kliniczne.

Słowa kluczowe: zwężenie zastawki aortalnej, wymiana zastawki aortalnej, proteza mechaniczna, hemoliza, odległe wyniki kliniczne.

Address for correspondence: Bartłomiej Perek MD, PhD, Department of Cardiac Surgery and Transplantology, Poznan University of Medical Sciences, 1/2 Długa St, 61-848 Poznan, Poland, phone: +48 6185492 10, e-mail: bperek@yahoo.com

Received: 1.09.2017, accepted: 3.09.2017. 


\section{Introduction}

Replacement of severely stenotic aortic valves with artificial prostheses has been an accepted therapeutic option [1]. Although aortic valve replacement (AVR) is associated with favorable long-term survival as compared to patients treated medically [2, 3], presence of an artificial substitute may be associated with early and late complications that can have a marked impact on functional status and quality of life $[4,5]$. Neither commercially available mechanical nor biological valves provide ideal laminar central blood flow as is noted through normal native aortic valves [6, 7]. Additionally, all prostheses, especially of small diameter, cause resistance for blood ejected during systole from the left ventricle [8]. The aforementioned factors may contribute to damage of blood cell components and eventually lead to hemolysis. Severe symptomatic hemolysis with anemia is a rare complication after prosthetic valve implantations and, if present, is usually observed after mitral valve replacement with evident periprosthetic leak [9]. However, a more prevalent prosthesis-related adverse event is subclinical hemolysis.

Up to now many types of mechanical valves have been used. On-X prostheses (On-X Life Technologies Inc., USA) are the latest generation and have been in routine clinical use for approximately 15 years $[4,10]$. Although the hemolysis incidence of On-X prostheses was studied with reference to the older mechanical valves just after their introduction, according to our knowledge nobody has tried to associate subclinical hemolysis with outcomes in the longterm follow-up period.

\section{Aim}

The purpose of the present study was to evaluate the prevalence of late prosthesis-related subclinical hemolysis and its impact on clinical status in a group of patients after AVR with On-X Conform mechanical prostheses.

\section{Material and methods \\ Patients selection}

The prospective study included 84 consecutive patients (60 males and 24 females) with the mean age of $58.3 \pm 10.3$ years who underwent aortic valve replacement with On-X mechanical prostheses (AVR) for isolated severe aortic stenosis. They were retrospectively split into two groups: group $\mathrm{H}(n=12 ; 14.3 \%)$ with a diagnosis of subclinical hemolysis and group C ( $n=72 ; 85.7 \%)$ without laboratory evidence of hemolysis. Hemolysis was defined according to criteria previously adopted by Laflamme that comprised one major (lactate dehydrogenase (LDH) activity > $234 \mathrm{IU} / \mathrm{l}$ ) and three minor variables (low hemoglobin content $(<124 \mathrm{~g} / \mathrm{l}$ for women and < $138 \mathrm{~g} / \mathrm{l}$ for men), low haptoglobin concentration $(<0.5 \mathrm{~g} / \mathrm{l})$ and high percentage of reticulocytes $(\geq 2 \%)$ ) [11]. If one major and two minor ones were present, hemolysis was diagnosed.

The demographics and selected preoperative clinical data of patients in both groups are outlined in Table I.

Patients who required simultaneous cardiac surgical and cardiologic interventions were excluded from the study. Subjects with even trivial perivalvular leak in the last follow-up echocardiographic examination and with

Tab. I. Preoperative demographics, selected laboratory and echocardiographic data

\begin{tabular}{|c|c|c|c|}
\hline Variables $^{1}$ & $\begin{array}{l}\text { Group H } \\
(n=12)\end{array}$ & $\begin{array}{l}\text { Group C } \\
(n=72)\end{array}$ & $P$-value* \\
\hline Age [years] & $64.8 \pm 7.7$ & $57.1 \pm 10.4$ & 0.006 \\
\hline Gender M/F & $4(33.3) / 8(66.7)$ & $56(77.8) / 16(22.2)$ & 0.011 \\
\hline Height [m] & $1.62 \pm 0.04$ & $1.73 \pm 0.11$ & $>0.001$ \\
\hline Weight [kg] & $82.2 \pm 15.6$ & $87.6 \pm 12.6$ & 0.274 \\
\hline BMI $\left[\mathrm{kg} / \mathrm{m}^{2}\right]$ & $30.2 \pm 4.5$ & $29.0 \pm 3.9$ & 0.205 \\
\hline $\mathrm{BSA}\left[\mathrm{m}^{2}\right]$ & $1.89 \pm 0.18$ & $2.03 \pm 0.19$ & 0.024 \\
\hline \multicolumn{4}{|c|}{ Laboratory parameters: } \\
\hline $\mathrm{HBG}[\mathrm{g} / \mathrm{ll}$ & $137.3 \pm 17.0$ & $144.5 \pm 16.6$ & 0.085 \\
\hline $\mathrm{HCT}$ & $0.41 \pm 0.03$ & $0.42 \pm 0.05$ & 0.654 \\
\hline $\mathrm{TBIL}[\mu \mathrm{mol} / \mathrm{l}]$ & $11.2 \pm 2.8$ & $11.8 \pm 5.2$ & 0.846 \\
\hline $\mathrm{LDH}[\mathrm{IU} / \mathrm{I}]$ & $232.4 \pm 28.0$ & $239.3 \pm 32.9$ & 0.718 \\
\hline \multicolumn{4}{|c|}{ Echocardiographic variables: } \\
\hline LVEDD [mm] & $5.2 \pm 1.0$ & $5.0 \pm 0.8$ & 0.613 \\
\hline LVPWd [mm] & $12.7 \pm 3.5$ & $15.8 \pm 3.1$ & 0.043 \\
\hline Ao annulus [mm] & $2.9 \pm 0.6$ & $3.6 \pm 0.5$ & 0.002 \\
\hline Ao STJ $[\mathrm{mm}]$ & $3.3 \pm 0.2$ & $4.1 \pm 0.6$ & 0.010 \\
\hline PPG [mm Hg] & $88.9 \pm 17.6$ & $85.4 \pm 19.2$ & 0.815 \\
\hline
\end{tabular}

${ }^{1}$ Continuous variables are expressed as mean \pm standard deviation, categorical variables as numbers (\%); ${ }^{*} p$-value group $\mathrm{H}$ vs. group C. Ao annulus - diameter of aortic annulus, Ao ST - diameter of aorta at sino-tubular junction level, BMI - body mass index, BSA - body surface area, HBG - hemoglobin concentration, HCT hematocrit, LDH - lactate dehydrogenase activity, LVEDD - left ventricular end-diastolic dimension, LVPWd - left ventricular posterior wall in diastole, PPG - peak pressure gradient, TBIL - total bilirubin concentration 
any clinical abnormalities that could theoretically influence haptoglobin concentration (e.g., acute infections, chronic inflammatory or rheumatic diseases, diabetes mellitus) were also discarded from further analysis.

The study protocol conforms to the ethical guidelines of the Declaration of Helsinki as reflected in a priori approval by the institution's human research committee. Informed consent was obtained from each study participant.

\section{Preoperative assessment}

Final diagnosis of severe aortic valve disease and indications for surgery were established by means of transthoracic echocardiographic (TTE) examination $(M+2 D+$ Doppler). Preoperative clinical status was assessed according to the New York Heart Association (NYHA) functional classification. Additionally, all subjects before surgery had blood samples taken and the findings in blood morphology and biochemical examinations were analyzed.

\section{Surgery}

All operations were performed via full median sternotomy using cardio-pulmonary bypass (CPB) in moderate hypothermia $\left(28^{\circ} \mathrm{C}\right)$ and cardioplegic cardiac arrest according to the St Thomas Hospital II formula. The CPB was conducted through an arterial cannula introduced to the ascending aorta and a two-staged venous one to the right atrium as described previously [12]. After the ascending aorta was opened, the aortic valve was completely removed and supra-annular OnX Conform (ACE models) mechanical aortic prostheses were implanted using non-everting mattress 2-0 sutures with Teflon pledges.

\section{Postoperative analysis}

After discharge, patients were followed up in the outpatient clinic and regular clinical and echocardiographic check-ups were carried out. At the end of the follow-up period, clinical status according to NYHA classification was assessed again, detailed TTE carried out and blood samples were taken. Blood morphology and reticulocyte counts, and biochemical examinations including assessment of parameters such as LDH activity, total bilirubin and haptoglobin concentrations were performed. All but one (haptoglobin) were carried out in the hospital central laboratory by mean of standard methods. Human Haptoglobin ELISA Kit (ab108856, Abcam, USA) was applied to calculate haptoglobin concentration and this study was done in the Department of Histology and Embryology.

\section{Data management and statistical analysis}

To check normality of continuous variables the ShapiroWilk $W$ test was performed. Normally distributed data are presented as the means \pm standard deviations and compared with unpaired Student's $t$ test. Categorical and ordinal variables are expressed as numbers $(n)$ and percentages (\%) and they were analyzed using the Mann-Whitney $U$ test. A $p$-value $<0.05$ was considered statistically significant. All

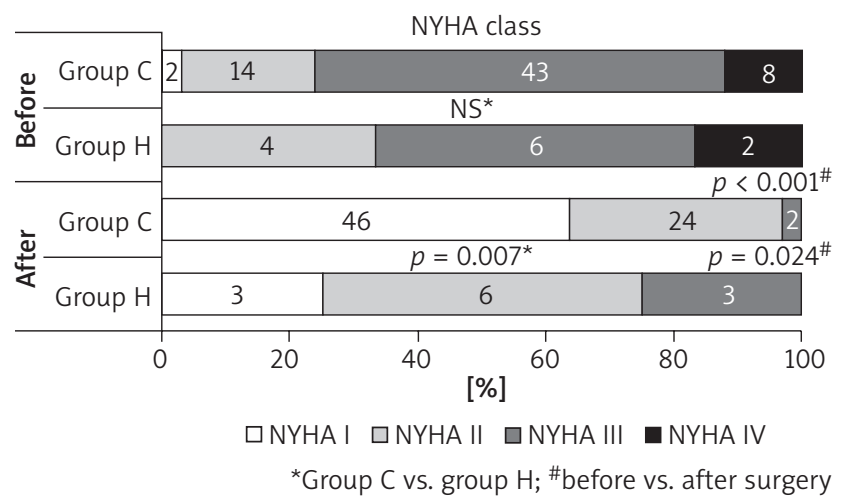

Fig. 1. NYHA class before and after surgery. Functional class according to NYHA classification did not differ between group $\mathrm{H}$ and $\mathrm{C}$ before surgery, while after the operation it improved in both groups, although at the end of follow-up this improvement was significantly less pronounced in group $\mathrm{H}$ than in group $\mathrm{C}$

statistical analyses were performed using Statistica 10.0 for Windows software (StatSoft, Inc., Tulsa, OK, USA).

\section{Results}

\section{Study participants}

Out of 93 patients primarily selected for participation in our study two were disqualified as aortic aneurysm requiring simultaneous surgical intervention was diagnosed intraoperatively, three died during the follow-up period that lasted $66.7 \pm 10.2$ months, one had mild perivalvular leak of no clinical significance in the last echocardiographic followup examination and three others denied their consent for participation in the study. Eventually, complete clinical data were available for 84 individuals. Among them, 18 (21.4\%) patients received On-X 19 ACE, 32 (38.1\%) On-X 21 ACE and 34 (40.5\%) On-X 23 ACE prostheses.

\section{Incidence of hemolysis and functional status}

The percentage of subjects who satisfied the aforementioned criteria of hemolysis in the whole group with properly working prostheses was $14.3 \%$ and it depended on the diameter of the implanted valve. This percentage reached the highest value of $33.3 \%$ for the smallest prostheses (On-X 19 ACE model), moderate (18.8\%) for On-X 23 ACE prostheses and was 0 for the biggest implants (On-X 25 ACE). Moreover, patients with subclinical hemolysis (group $\mathrm{H}$ ) were older (mean age: 64.8 years vs. 57.1 years) and more frequently were woman (67\% vs. $22 \%$ ) than group C subjects (Tab. I).

Although the AVR procedure resulted in significant improvement in functional status assessed according to the NYHA classification, this improvement was markedly less pronounced in group $\mathrm{H}$ (Fig. 1). Before surgery, $76.4 \%$ of patients $(n=55)$ in group C and $66.7 \%(n=8)$ in group H were found in NYHA classes III and IV. After surgery their percentage decreased significantly in both subsets of patients to $2.8 \%$ in group C ( $p<0.001$ vs. before) and to $25 \%$ in group $\mathrm{H}$ ( $p=0.024$ vs. before). However, at the end of the follow-up the median NYHA class in group C (I (I, III)) was significantly lower than in group $\mathrm{H}(\mathrm{II}(\mathrm{I}, \mathrm{III}))(p=0.007)$. 


\section{Laboratory parameters}

Patients in group $\mathrm{H}$ had significantly lower hemoglobin and hematocrit than group $\mathrm{C}$ subjects and more patients after surgery manifested decreased values of both parameters in comparison to preoperative examinations (Tab. II). Additionally, red cell indices - mean corpuscular volume (MCV), mean corpuscular hemoglobin $(\mathrm{MCH})$ - and serum iron concentration accompanied by a decrease in total iron binding capacity (TIBC) indicated an iron, at least relative, deficiency in group $\mathrm{H}$. Activity of $\mathrm{LDH}$, a major criterion of hemolysis, was markedly higher in group $\mathrm{H}$ than in $\mathrm{C}$. Interestingly, the difference in total bilirubin level did not reach statistical significance between groups. Other findings in the postoperative laboratory examination are summarized in Table II.

\section{Echocardiographic parameters}

Transprosthetic systolic both peak and mean gradients were higher whereas effective aortic orifice area (AVA) was

Tab. II. Laboratory parameter at the last follow-up examination

\begin{tabular}{lccc} 
Variables $^{1}$ & $\begin{array}{c}\text { Group H } \\
(n=12)\end{array}$ & $\begin{array}{c}\text { Group C } \\
(n=72)\end{array}$ & P-value* \\
RBC $\left[\times 10^{12} / \mathrm{l}\right]$ & $4.97 \pm 0.49$ & $4.57 \pm 0.12$ & $<0.001$ \\
\hline HBG $[\mathrm{g} / \mathrm{ll}]$ & $131.2 \pm 5.1^{\#}$ & $149.9 \pm 15.3$ & $<0.001$ \\
\hline $\begin{array}{l}\text { HBG follow-up } \\
<\mathrm{HBG} \text { baseline }\end{array}$ & $4(33.3)$ & 0 & 0.039 \\
\hline HCT & $0.39 \pm 0.01^{\#}$ & $0.45 \pm 0.04$ & $<0.001$ \\
\hline HCT follow-up & $6(50.0)$ & $4(5.6)$ & 0.014 \\
$<$ HCT baseline ${ }^{2}$ & & & \\
\hline MCV $[\mathrm{fl}]$ & $87.3 \pm 3.5$ & $90.8 \pm 3.5$ & 0.024 \\
\hline MCH $[\mathrm{fmol}]$ & $1.80 \pm 0.07$ & $1.87 \pm 0.09$ & 0.026 \\
\hline TBIL $[\mu \mathrm{mol} / \mathrm{ll}]$ & $9.6 \pm 3.8$ & $8.8 \pm 3.7$ & 0.612 \\
\hline Iron $[\mu \mathrm{g} / \mathrm{l}]$ & $63.5 \pm 9.8$ & $83.2 \pm 28.9$ & $<0.001$ \\
\hline TIBC $[\mu \mathrm{g} / \mathrm{ll}]$ & $309 \pm 17$ & $347 \pm 41$ & $<0.001$ \\
\hline LDH $[\mathrm{IU} / \mathrm{ll}]$ & $274.2 \pm 28.6^{\#}$ & $248.6 \pm 38.5$ & 0.015 \\
\hline
\end{tabular}

${ }^{1}$ Continuous variables are expressed as mean \pm standard deviation, categorical variables as numbers (\%); ${ }^{2}$ number of patients; ${ }^{*} p$-value group $\mathrm{H}$ vs. group C; \#significant difference vs. before surgery (baseline). HBG - hemoglobin concentration, $\mathrm{HCT}$ - hematocrit, $\mathrm{LDH}$ - lactate dehydrogenase activity, $\mathrm{MCH}$ mean corpuscular hemoglobin, MCV - mean corpuscular volume, RBC - red blood cell count, TBIL - total bilirubin concentration, TIBC - total iron binding capacity

Tab. III. Selected follow-up echocardiographic parameters (M + 2D + Doppler)

\begin{tabular}{lccc} 
Variables $^{1}$ & $\begin{array}{c}\text { Group H } \\
(n=12)\end{array}$ & $\begin{array}{c}\text { Group C } \\
(n=72)\end{array}$ & P-value* \\
LVEDD [mm] & $4.5 \pm 0.5^{\#}$ & $4.8 \pm 0.6^{\#}$ & 0.140 \\
\hline LVPWd [mm] & $12.6 \pm 2.2$ & $11.8 \pm 2.1^{\#}$ & 0.074 \\
\hline PPG [mm Hg] & $29.5 \pm 6.8$ & $24.9 \pm 4.4$ & 0.042 \\
\hline MPG [mm Hg] & $17.4 \pm 4.5$ & $13.6 \pm 3.1$ & 0.002 \\
\hline AVA [cm $\left.{ }^{2}\right]$ & $1.25 \pm 0.22$ & $1.58 \pm 0.33$ & $<0.001$ \\
\hline
\end{tabular}

${ }^{1}$ Continuous variables are expressed as mean \pm standard deviation; ${ }^{*} p$-value group H vs. group C; "\#significant difference vs. before surgery (baseline). AVA - aortic valve area, LVEDD - left ventricular end-diastolic dimension, LVPWd - left ventricular posterior wall in diastole, MPG - mean pressure gradient, PPG - peak pressure gradient smaller in group $\mathrm{H}$ than in group C. Although left ventricular end-diastolic dimension (LVEDD) normalized at the end of the follow-up period in both groups, regression of LV hypertrophy calculated on the basis of LV posterior wall thickness was evident only in group C (Tab. III).

\section{Discussion}

Prosthesis-induced hemolysis, both the severe form resulting in anemia and the subclinical one, is an obligatory parameter to be assessed as a marker of safety and biocompatibility at the time of introduction of the novel commercially available valves. Such studies were also carried out with On-X mechanical valves [4, 13].

The rate of subclinical hemolysis of properly functioning commercially available prostheses varies between a few percent and almost $90 \%$, and it depends on many factors [14-16]. Among the most important are prosthesis design and implantation position. The highest rate was reported for early generation mechanical valves [15] in the mitral position and the lowest for modern aortic bioprostheses [14]. The new generation On-X prostheses are made of pure pyrolytic carbon (free of silicone) with exceptional design that allows opening of discs up to $90^{\circ}$ and a shorter leaflet closing angle [17]. All of them theoretically reduce the turbulences and should inhibit platelet aggregation followed by thrombus formation and also hemolysis rate. In spite of this unique design, we confirmed earlier findings that subclinical hemolysis may still be noted in 10-20\%.

Currently, there is no commonly accepted definition of subclinical hemolysis; thus it is not easy to compare findings of the published reports as researchers adopted different criteria [11, 18]. At least a few markers of hemolysis such as plasma LDH activity, concentrations of haptoglobin, hemoglobin, bilirubin or reticulocyte rate have been taken into account. In some papers, elevated LDH, although to a different level above the normal upper limit, was enough to diagnose subclinical hemolysis $[18,19]$. In the others, more criteria had to be satisfied [11]. In consequence, the rate of subclinical hemolysis in properly working prostheses is within a wide range even for the same prosthesis in the same position. As we adopted relatively strict criteria of hemolysis, the incidence of $15 \%$ after mechanical AVR was relatively low. Moreover, it is comparable to transcatheter aortic valve implantation patients [11].

We have proved that the size of the implanted prosthesis matters. The largest one was noted for the smallest valves (On-X 19 ACE model). Additionally, peak and mean systolic transvalvular gradients were significantly higher in group $\mathrm{H}$ patients. It must be stressed that there were more women, older and smaller patients and more individuals had narrow aortic annulus in group $\mathrm{H}$. These factors probably determined the choice of implanted prostheses. Previous reports are not consistent with regards to the impact of valve size and transvalvular pressure gradient on hemolysis incidence $[11,16,18]$. Although it seems logical that smaller prostheses cause more turbulence and are associated with higher resistance to blood flow that eventually lead 
to hemolysis, some authors of previous reports failed to prove the existence of such correlations $[16,18]$. Josa et al. reported that subclinical hemolysis was significantly more frequent after mitral valve and double valve replacement than after aortic valve replacement, while it was unrelated to prosthetic size or to geometric area index even in those cases with moderate patient-prosthesis mismatch [16]. The latter was defined as effective orifice area index equal to or less than $0.85 \mathrm{~cm}^{2} / \mathrm{m}^{2}[16]$.

According to our knowledge, this study is the first to associate prosthesis-related subclinical hemolysis to the longterm outcomes after AVR with On-X valves. Hemolysis, especially that requiring blood transfusion, is a well-recognized marker of severity of paravalvular leak and is considered as an indication for repeat surgery or intravascular occlusion [20]. However, the impact of subclinical hemolysis on functional improvement late after an operation for aortic stenosis in patients with properly functioning prostheses is not known. Although functional status assessed according to the NYHA classification was significantly better for patients without any signs of hemolysis (group C), we must remember that many other factors may contribute to worse status. They include anemia with lower MCV and at least relative iron deficiency accompanied by depressed TIBC. Previously, it was found that excessive hemolysis may be associated with iron-deficiency anemia [21]. Moreover, not only a small aortic orifice but also hypertrophic LV myocardium, particularly within the outflow tract, was shown to contribute to anemia development [22]. In our study we found not only a smaller aortic orifice area but also persistent LV hypertrophy in group $\mathrm{H}$ as compared to group $\mathrm{C}$. Thus, it cannot be excluded that not only hemolysis itself but also other factors negatively impacted the long-term follow-up outcomes.

We are aware of study limitations. The low number of prospectively evaluated patients is the main drawback of our study. Additionally, the number of subjects who met hemolysis criteria $(n=12)$ was even smaller, and this fact made it impossible to perform reliable multivariate analysis. We plan to continue our study with more participants and a longer follow-up period.

\section{Conclusions}

Our study proved that prosthesis-induced hemolysis is seen even in the latest generation of mechanical aortic prostheses, particularly of smaller diameter, and it may have an impact on functional status in the long-term follow-up.

\section{Disclosure}

Authors report no conflict of interest.

\section{References}

1. Nishimura RA, Otto CM, Bonow RO, Carabello BA, Erwin JP 3rd, Fleisher LA, Jneid H, Mack MJ, McLeod CJ, O'Gara PT, Rigolin VH, Sundt TM $3^{\text {rd }}$, Thompson A. 2017 AHA/ACC Focused Update of the 2014 AHA/ACC Guideline for the Management of Patients With Valvular Heart Disease: A Report of the American College of Cardiology/American Heart Association Task Force on Clinical Practice Guidelines. J Am Coll Cardiol 2017; 70: 252-289.
2. Belkin RN, Khalique O, Aronow WS, Ahn C, Sharma M. Outcomes and survival with aortic valve replacement compared with medical therapy in patients with low-, moderate-, and severe-gradient severe aortic stenosis and normal left ventricular ejection fraction. Echocardiography 2011; 28: 378-387.

3. Ozkan A, Hachamovitch R, Kapadia SR, Tuzcu EM, Marwick TH. Impact of aortic valve replacement on outcome of symptomatic patients with severe aortic stenosis with low gradient and preserved left ventricular ejection fraction. Circulation 2013; 128: 622-631.

4. Laczkovics A, Heidt M, Oelert H, Laufer G, Greve H, Pomar JL, Mohr FW, Haverich A, Birnbaum D, Regensburger D, Palatianos G, Wolner E. Early clinical experience with the On-X prosthetic heart valve. J Heart Valve Dis 2001; 10: 94-99.

5. Cho IJ, Moon J, Shim CY, Jang Y, Chung N, Chang BC, Ha JW. Different clinical outcome of paravalvular leakage after aortic or mitral valve replacement. Am J Cardiol 2011; 107: 280-284.

6. Trauzeddel RF, Löbe U, Barker AJ, Gelsinger C, Butter C, Markl M, SchulzMenger J, von Knobelsdorff-Brenkenhoff F. Blood flow characteristics in the ascending aorta after TAVI compared to surgical aortic valve replacement. Int J Cardiovasc Imaging 2016; 32: 461-467.

7. von Knobelsdorff-Brenkenhoff F, Trauzeddel RF, Barker AJ, Gruettner H, Markl M, Schulz-Menger J. Blood flow characteristics in the ascending aorta after aortic valve replacement: a pilot study using 4D-flow MRI. Int J Cardiol 2014; 170: 426-433.

8. Perek B, Paluszkiewicz L, Misterski M, Sarnowski W, Jemielity M. Aortic valve replacement with On-X 21 mechanical prosthesis in patients with small aortic root -5 years' experience. Kardiochir Torakochirurgia Pol 2007; 4: 137-142.

9. Choi JH, Park YH, Yun KW, Lee SH, Kim JS, Kim J, Kim JH, Je HG, Lee SK, Chun KJ. Intractable hemolytic anemia after mitral valve repair: a report of three cases. Echocardiography 2013; 30: E281-E284.

10. Chaudhary R, Garg J, Krishnamoorthy P, Shah N, Feldman BA, Martinez MW, Freudenberger R. On-X valve: the next generation aortic valve. Cardiol Rev 2017; 25: 77-83.

11. Laflamme J, Puri R, Urena M, Laflamme L, DeLarochellière H, Abdul-Jawad A tisent O, del Trigo M, Campelo-Parada F, DeLarochellière R, Paradis JM, Dumont E, Doyle D, Mohammadi S, Côté M, Pibarot P, Laroche V, Rodés-Cabau J. Incidence and risk factors of hemolysis after transcatheter aortic valve implantation with a balloon-expandable valve. Am J Cardiol 2015; 115: 1574-1579.

12. Perek B, Misterski M, Stachowiak W, Buczkowski P, Stefaniak S, Puślecki M, Urbanowicz T, Budniak W, Jemielity M. The impact of coronary artery disease severity on late survival after combined aortic valve replacement and coronary artery bypass grafting - experience of a single cardiac surgery center. Kardiochir Torakochirurgia Pol 2014; 11: 361-366.

13. McNicholas KW, Ivey TD, Metras J, Szentpetery S, Marra SW, Masters RG, Dilling EW, Slaughter MS, Mack MJ. North American multicenter experience with the On-X prosthetic heart valve. J Heart Valve Dis 2006; 15: 73-78.

14. Mecozzi G, Milano AD, De Carlo M, Sorrentino F, Pratali S, Nardi C, Bortolotti U. Intravascular hemolysis in patients with new-generation prosthetic heart valves: a prospective study. J Thorac Cardiovasc Surg 2002; 123: 550-556.

15. Febres-Roman PR, Bourg WC, Crone RA, Davis RC Jr, Williams TH. Chronic intravascular hemolysis after aortic valve replacement with lonescu-Shiley xenograft: comparative study with Bjork-Shiley prosthesis. Am J Cardiol 1980; 46: 735-738.

16. Josa M, Castellá M, Paré C, Bedini JL, Cartańá R, Mestres CA, Pomar JL, Mu let J. Hemolysis in mechanical bileaflet prostheses: experience with the $\mathrm{Bi}$ carbon valve. Ann Thorac Surg 2006; 81: 1291-1296.

17. Ely JL, Emken MR, Accuntius JA, Wilde DS, Haubold AD, More RB, Bokros JC. Pure pyrolytic carbon: preparation and properties of a new material, On-X carbon for mechanical heart valve prostheses. J Heart Valve Dis 1998; 7: 626-632.

18. Suedkamp M, Lercher AJ, Mueller-Riemenschneider F, LaRosee K, Tossios P, Mehlhorn U. Hemolysis parameters of St. Jude Medical: hemodynamic plus and regent valves in aortic position. Int J Cardiol 2004; 95: 89-93.

19. Birnbaum D, Laczkovics A, Heidt M, Oelert H, Laufer G, Greve H, Pomar JL, Mohr F, Haverich A, Regensburger D. Examination of hemolytic potential with the On-X(R) prosthetic heart valve. J Heart Valve Dis 2000; 9: 142-145.

20. Wells JA, Condado JF, Kamioka N, Dong A, Ritter A, Lerakis S, Clements S, Stewart J, Leshnower B, Guyton R, Forcillo J, Patel A, Thourani VH, Block PC Babaliaros V. Outcomes after paravalvular leak closure: transcatheter versus surgical approaches. JACC Cardiovasc Interv 2017; 10: 500-507.

21. Thotakura S, Costa SM, Cable C. Iron deficiency and hemolytic anemia reversed by ventricular septal myectomy. Proc (Bayl Univ Med Cent) 2015; 28: 494-495.

22. Kubo T, Kitaoka H, Terauchi Y, Tamura S, Okawa M, Yamasaki N, Yabe T, Doi YL. Hemolytic anemia in a patient with hypertrophic obstructive cardiomyopathy. J Cardiol 2010; 55: 125-129. 